\title{
Effectiveness of 3CM Learning Model with Blended Learning on Improving Creative Thinking Ability in Mathematical Problem Solving
}

\author{
Wahyudi $^{1}$, St. Budi Waluya ${ }^{2}$, Hardi Suyitno ${ }^{3}$, Isnarto ${ }^{4}$ \\ 1,2,3,4 Mathematics Education, Postgraduate Program, Universitas Negeri Semarang, Indonesia \\ ${ }^{1}$ Corresponding email: yudhisalatiga @ gmail.com
}

\begin{abstract}
Creative is one of the most important and highest competencies in Bloom's latest taxonomy, so it is necessary to have everyone including preservice teachers. Creative not only in producing products in the form of objects, but can be creative in terms of thinking in solving problems, including mathematic problems. This study aims to describe and test the effectiveness of $3 \mathrm{CM}$ learning model with blended learning to improve students' creative thinking ability in mathematical problem solving. This research uses pre experimental design with one group pre-test post-test design pattern. Creative thinking ability is measured by test technique and then in triangulation with observation and interview. To see the effectiveness of 3CM learning with blended learning done with paired T test with assisted with SPSS program then triangulated with observation and interview. Based on the test results, obtained the average pre-test 60.51 and post-test 75.96. Result of paired $\mathrm{T}$ tests, test got sig value. (2-tailed) 0.000. It shows that 3CM learning with blended learning effectively improves students' creative thinking ability in solving problems. This happens because learning gives students the opportunity to think systematically by beginning by criticizing the interesting contextual problems and ending with meaningful reflection with adequate learning resources both when faceto-face and online.
\end{abstract}

Keywords: 3CM learning model, blended learning, creative thinking, mathematical problem solving

\section{Introduction}

One of the goals of Indonesian education is to develop the potential of learners to become creative human beings (Law No. 20 of 2003). Creative is the highest level of competence in Bloom's latest taxonomy (Stanny, 2016). Creative not only in producing products, but creative in thinking, including mathematical creative thinking. The ability to think creatively grows from one's creativity. Creativity arises also because of the opportunity to do so. Creative is also one of the main components in $21^{\text {st }}$ century education (Mann, 2006; Tindowen, Bassig, \& Cagebas, 2017). Therefore, the content-exporter curriculum emphasizes the development of creative thinking skills for learners (Vale \& Barbosa, 2015; Sternberg, 2006).

Real problems in learning, not all mathematics learning in schools provide opportunities for learners to develop creative thinking skills included in the mathematics field. Learning only in order to achieve the target test scores and less to give learners experience to think, logical reason and solving problems (Rachmawati, 2012). This condition also occurs in learning mathematics in colleges including pre-service teachers. Mathematics learning has not given students the opportunity to improve their ability to have a logical reason and creative thinking in solving problems (Suarma \& Kusumah, 2016; Wahyudi, Waluya, \& Rochmad, 2018).

In addition has to be contextual, the language aspect becomes something that is very important in learning mathematics. Because the wrong language will give the wrong understanding, for example the mistake of learners in interpreting the word in the matter. So the process of mathematical communication in this case do not work well (Zevenbergen, 2004; Hudojo, 1988; Anthony \& Walshaw, 2009). Good language will make mathematics become interesting information, easy to remember and stored long in the learner learners with a true and stable schemata. The schemata will be utilized to solve the given problem. Someone takes advantage of memory, representation and manipulation to solve a given mathematical problem. This ability is called problem-solving ability (Matlin, 2009).

These results serve as a further step to formulate how mathematics learning can provide opportunities for students to develop creative thinking skills in the field of mathematics in a cool and fun way, easy to remember as a good memory, but give their 
critical expression and creative thinking and give meaning in their life. So that required the design of learning with the study of the right theory in the hope can provide a cool learning atmosphere as well as the opportunity to think critically, creatively and meaningfully. Learning should provide a memorable experience and opportunities learners utilize the left and right brain in the cool activities, critical, creative, and meaningful that named with 3CM Learning. This learning model adopts and combines contextual learning, realistic mathematics, and meaningful learning of Brownell and David Ausubel. Learning begins with the giving of contextual problems close to the activities, culture and social reality of human beings so that it becomes a memorable, imaginary, represented and manipulated experience in the student's cognitive maps in a good schemata (Wahyudi \& Waluya, 2017). Learning will provide a balance between the cognitive and the feelings aspects. This will provide a balance between the left-brain work (logic source) and the right brain (the source of spiritual feeling) (Nurhalim, 2003). Feelings are one component of creative thinking ability (creativity). With this balance will be formed prospective teachers who have the ability to think creatively good. The ability to think creatively is a combination of logical thinking and diverging thinking. While the ability to think logically involves a rational and systematic process to examine and validate the conclusions of the resulting problem solving (Siswono, 2010).

Besides, it is necessary to have wide learning rides for students to find information related to problem solving, from fluency, flexibility, originality, and elaboration aspects from many sources. This can be done by utilizing technology as a learning tool and learning resource. To package this kind of learning model requires special skills for a teacher. Not enough content, or pedagogical learning skills, but should be able to combine the two. Not only required a special ability that is the use of technology in learning (technological). By combining these three abilities then the classroom learning will be more interesting, efficient and meaningful for the students. Learning is packaged in face-toface and online learning (blended learning). This lesson will give students the opportunity to look for problem solving information provided with creative new solutions. With this learning process will provide opportunities for learners to get many resources and a lot of learning from others to inspire them in solving the problems given.

\section{Methods}

This study used pre experimental design with one group pretest-posttest design pattern. Where one class was used as experimental class to be given learning with $3 \mathrm{CM}$ learning model. Before studying with $3 \mathrm{CM}$ learning model, students were given pretest to see their initial ability. After following the learning, students were given posttest to see the impact of $3 \mathrm{CM}$ learning. The effectiveness of $3 \mathrm{CM}$ learning model, seen from the average difference of pretest and posttest results.

Population in this research were students of Study Program of Primary School Teacher Education class of 2017. Subject was taken by random sampling technique, by given lottery to representation of 7 existing classes, selected class A as sample of research. There were 27 students in this sample.

The data were collected using test, observation, and interview techniques. The test was used to measure the creative thinking ability and the results were compared and analyzed using SPSS through Paired samples T-test.

Data analysis techniques to see the effectiveness of $3 \mathrm{CM}$ learning model is done by comparing the results of pretest and posttest creative thinking ability. Pretest and posttest results are analyzed, classified and compared using Paired samples T-test with SPSS program. Data of initial ability of mathematical creative thinking are classified based on the creative thinking level. (Creative Thinking Level) CTL 3 (Creative), CTL 2 (Creative Enough), CTL 1 (Less Creative), CTL (Creative Creativity), Creative Thinking Level (CTL), and CTL 0 (Not Creative).

Table 1. Category determination the level of creative thinking skills

\begin{tabular}{ccc}
\hline Interval & $\begin{array}{c}\text { Creative Thinking } \\
\text { Level (CTL) }\end{array}$ & Category \\
\hline $78-100$ & CTL 3 & Creative \\
$52-77$ & CTL 2 & Creative \\
& & Enough \\
$26-51$ & CTL 1 & Less Creative \\
$0-25$ & CTL 0 & Not Creative \\
\hline
\end{tabular}




\section{Results and Discussion Results}

Before having the test, the students get the learning with 3CM learning model for 10 weeks (10 meetings). Learning is done faceto-face and online. Implementation of 3CM learning is done in seven steps of learning (syntax) that is, motivation, contextual problem, critical issue, problem solving, concept implementation in creative product, confirmation, reflection.

\section{Mathematical Creative Thinking Initial Level}

Before and after learning in 3CM learning models, students are given pretest and posttest to gain initial ability and end-ability in their creative thinking. The mean of pretest and posttest results are 60.52 and 75.96 with the standard deviation of pretest results of 9.60 and posttest 6.36 with the standard of precast error 1.85 and posttest 1.22 . These results indicate that the creative thinking ability of posttest results closer to the mean grade compared with the pretest results. Thus, the value of posttest variation is smaller than the pretest results seen from the mean value (mean).

Pretest data shows that, students' initial ability before following learning with $3 \mathrm{CM}$ learning model is in medium and low category that is $92,59 \%$ (25 people from 27 people). Only $7.41 \%$ ( 2 people) are in creative category. This result shows that students' creative thinking ability still needs improvement.

After following the 3CM learning method, there is an increasing number of students, who have creative and medium category. Creative category improvement from $7.41 \%$ ( 2 people) to $40.74 \%$ (11 people). The number of students with moderate and weak categories decreased from $92.59 \%$ (25 people) decreased to $59.26 \%$ (16 people). This shows an increase in creative thinking ability before and after following the learning with $3 \mathrm{CM}$ learning.

This result is supported by observations when they are working on test questions. Students work on the problem independently with the stages of solving the problems that have been directed and produce several solutions, although not yet according to aspects of creative thinking can be implemented optimally. Descriptions of observation results are seen in Table 2 .

Table 2. Observation Results of Student Activities When Working on Tests

\begin{tabular}{lccc}
\hline \multicolumn{1}{c}{ CTS } & \multicolumn{3}{c}{ Questions } \\
Aspect & 1 & 2 & 3 \\
\hline Fluency & 20 & 20 & 22 \\
Flexibility & 18 & 16 & 15 \\
Originality & 12 & 13 & 11 \\
Elaboration & 11 & 11 & 12 \\
\hline
\end{tabular}

To see further the impact of the application of 3CM learning in learning it is necessary to test the effectiveness of the model by using paired $\mathrm{T}$ tests. This was chosen because the study design used a quasiexperiment with one group pretest posttest design. There is a disadvantage of this design because it uses only one class. Here are the results of paired $\mathrm{T}$ tests that begin with the normality test data as shown in Table 3.

Table 3. The Normality Test of Creative Thinking Skills Pre-test and Post-test

\begin{tabular}{lrrr}
\hline & \multicolumn{3}{c}{ Shapiro-Wilk } \\
& Statistic & df & \multicolumn{1}{c}{ Sig. } \\
\hline Pre Test & .930 & 27 & .068 \\
Post Test & .932 & 27 & .077 \\
\hline
\end{tabular}

The number of students taken as a sample of only 27 people so that the results of normality taken is the result of normality with Shapiro-Wilk. According to the data in Table 7 we get the Sig value. Pretest and Posttest of 0.068 and 0.077 are both greater than 0.05 so that both data are normally distributed. This result is a requirement for the following steps: Paired Samples T Test. The results obtained can be seen in Table 4 and Table 5.

Table 4. Paired Samples T-Test Creative Thinking Ability

\begin{tabular}{ccccc}
\hline \multicolumn{5}{c}{ Paired Samples Correlations } \\
\hline Pair 1 & $\begin{array}{c}\text { Pre Test } \\
\text { \& Post } \\
\text { Test }\end{array}$ & 27 & .777 & .000 \\
\hline
\end{tabular}


Table 5. Paired Samples T-test Creative Thinking Ability

\begin{tabular}{|c|c|c|c|c|c|c|c|c|}
\hline & \multicolumn{5}{|c|}{ Paind Difienates } & \multirow{3}{*}{ t } & \multirow{3}{*}{ df } & \multirow{3}{*}{ Sig $(2 \cdot$ rilad $)$} \\
\hline & \multirow[t]{2}{*}{ Mera } & \multirow[t]{2}{*}{$\begin{array}{c}\text { Stod. } \\
\text { Deviatisn }\end{array}$} & \multirow{2}{*}{$\begin{array}{l}\text { Std } \\
\text { Eemor } \\
\text { Mean }\end{array}$} & \multicolumn{2}{|c|}{$\begin{array}{l}\text { 95y Confidense } \\
\text { Intervil of the } \\
\text { Deffereace }\end{array}$} & & & \\
\hline & & & & Lower & Upper & & & \\
\hline Pair I Pre & & & & & & & & \\
\hline $\begin{array}{l}\text { Test - } \\
\text { Post } \\
\text { Test }\end{array}$ & -15.4 & 6.14 & 1.182 & .1787 & -13.01 & .13 .06 & 26 & .000 \\
\hline
\end{tabular}

Based on data of Table 6 and Table 7 it is found that the value of sig. $0.000<0.05$ and $t$ arithmetic (13.06) > t table (2.05) it is found that there are significant differences between pretest and posttest results. Where posttest results are better than the pretest results. Thus, it can be concluded that the application of $3 \mathrm{CM}$ learning is effective in improving students' creative thinking skills in solving math problems.

\section{Discussions}

Based on the results of data analysis and hypothesis testing, it found that the $3 \mathrm{CM}$ learning model with blended learning could improve students' creative thinking skills in solving mathematical problems. This happens because the learning situation is prepared and implemented in accordance with the context of student life, and in fun activities package. This is according to the current paradigm of learning mathematics, where mathematics is close to humans, mathematics is part of human culture (Hersh, 1997; Siswono, 2007; Rachmawati, 2012) and part of social reality (Ernest in Hersh, 1997; Zevenbergen, 2004). This is also according to the research of Wahyudi, Waluya, \& Rochmad (2018), learning with scaffolding in an interesting and correct way and using contextual problems can motivate students to want to learn mathematics and be able to solve mathematical problems. The interview results showed motivating with interesting, contextual, easy to imagine things, not always in the form of formulas and numbers, making them interested and willing to learn mathematics.

In addition, students can also experience directly through contextual events, students also get experience in online learning that has been prepared. Learning can be accessed at http://flearn.uksw.edu in mathematics problem solving courses. After students look at the problem of fiber criticizing the problems contained in the video that has been given, students create creative products as stated in the form provided that is to produce creative works in the form of power point animations for even number patterns (here is the link to the creative work form: click here). This condition provides opportunities for students to have enough vehicles as learning resources that can be accessed whenever and wherever they like. In addition, this model allows students to see creative and unusual problemsolving ways with interesting approaches to inspire them to produce problem solving in new ways. This is in accordance with the principle of creativity arising because there is an opportunity. There are $3 \mathrm{~N}$ activities (Niteni, Nerokke, Nambahi) taught by $\mathrm{Ki}$ Hajar Dewentara. This concept makes the thought that creativity will emerge if students are given the opportunity. The creativity that appears is still at a level that must see the example first. The results of the interview support this statement, students at the initial level tend to mimic so that raises ideas to think about other creative works. This is according to Hsieh's opinion (2011) the teaching style of a teacher can influence students' learning reflections (in this case student). Therefore, if you want to produce creative students, the lecturer must be creative first in designing and implementing learning. This is in line with the opinion of Morais \& Azevedo (2011), a good teacher must be creative so that it can be an example for students to create further. In addition to creativity, something that can be exemplified, teaching creativity is also one of the best and always evolving habits of teaching creative thinking and developing (Henriksen, 2016).

The concept of learning is also in accordance with the principle of a teacher according to $\mathrm{Ki}$ Hajar Dewatara namely ing ngarso sung tulodo, ing madyo mbangun karso, tut wuri handayani. Teachers must be able to be role models for their students, be able to build the spirit of students, but also must provide the widest possible opportunity for students to learn further to explore learning resources, elaborate so that students become independent people. Learning because of your own will, so learning does not have to wait to be given, but learns to find and find.

The success of this model improves mathematical problem solving abilities, also due to the obligation of students to produce creative work that is the result of their creative 
thinking in solving problems. Students are given wide opportunities to discuss with their team, find sufficient information and data and are not limited to the time and place and the role of lecturers directly. This is in accordance with the opinion of Boelens et al., (2017) learning must be able to stimulate student interaction, facilitate their learning process, and encourage an affective learning climate. Each of their learning activities has been designed and prepared from the beginning and explained to the students the target products that must be produced and how they can meet these targets. So that they in the team will try to meet the predetermined target.

Student creativity in solving mathematical problems also supported by a learning environment that fosters creativity among students themselves (Soh, 2017, Richardson \& Mishra, 2017). There is an opportunity for each group to present the results in a face-toface class, thus encouraging other groups to produce better work, and even better. This very positive learning environment triggers students with their teams to continue to improve their creative work. Lecturers in the form of learning simulations by lecturers using animation media, images and even videos of life realities that are close to students so that they are easy to understand also provide positive learning environment. This is consistent with the results of Tsai \& Chung's research, (2015), that a positive learning environment will make students motivated and creative to produce something useful.

\section{Conclusion}

Based on the results of data analysis and discussion, it can be concluded that $3 \mathrm{CM}$ learning with blended learning effectively improves students' problem solving in creative thinking abilities. This happens because learning gives students the opportunity to think systematically by beginning by criticizing the interesting contextual problems and ending with meaningful reflection with adequate learning resources both when face-to-face and online.

\section{References}

Anthony, G. \& Walshaw, M. 2009. Characteristics of Effective Teaching of Mathematics: A View from the West. Journal of Mathematics Education. Vol. 2,
No. 2, pp.147-164.

Boelens, Heij. 2017. The development of semantic blocking in children. British Journal of Development Psychology. 35(2)

310-315. https://doi.org/10.1111/bjdp.12178

Henriksen, Danah. (2016). The seven transdisciplinary habits of minds of creative teachers: An exploratory studi of award winning teachers. Teaching Skills and Creativity, Vol 22 December 2016, Pages 212-232. https://doi.org/10.1016/j.tsc.2016.10.007

Hersh, Reuben. 1997. What is Mathematics, Really?. London: Jonathan Cape.

Hsieh, S.W., et.al. (2011). Effects of teaching and learning styles on students' reflection levels for ubiquitous learning. Computers \& Education, Volume 57, Issue 1, August 2011, Pages 1194-1201. https://doi.org/10.1016/j.compedu.2011.0 1.004

Hudojo, H. 1988. Mengajar Belajar Matematika. Jakarta: Depdikbud Direktorat Jenderal Pendidikan Tinggi Proyek Pengembangan Lembaga Pendidikan Tenaga Kependidikan.

Mann, E. L. 2006. Mathematical creativity and school mathematics: Indicators of mathematical creativity in middle school students 1956. Dissertation Abstracts International Section A: Humanities and Social Sciences, 67, 461.

Matlin, M. 2009.Cognition, Seventh Edition. New York: John Wiley \& Sons, Inc.

Morais, Maria Fatima \& Azevedo, Ivete. (2011). What is a Creative Tecaher and What is a Creative Pupil? Perceptions of Teachers. Procedia Social and Behavioral Sciences, Vol 12, 2011, Page 330-339, https://doi.org/10.1016/j.sbspro.2011.02.0 42

Nurhalim, M. S. 2003. Pembinaan kreativitas menuju era global. Bandung: PT Alumni

Rachmawati, I. 2012. Eksplorasi Etnomatematika Masyarakat Sidoarjo. Ejournal Unnes.

Republik Indonesia. 2003. Undang-Undang No. 20 Tahun 2003 tentang Sistem Pendidikan Nasional. Presiden Republik Indonesia. Jakarta.

Siswono, T. Y. E. 2007. Pembelajaran Matematika Humanistik yang Mengembangkan Kreativitas Siswa. Yogyakarta: Universitas Sanata 
Dharma, 1-16.

Soh, K. 2017. Fostering student creativity through teacher behaviors. Thinking Skills and Creativity, 23, 58-66.

Stanny, C.J. (2016). Reevaluating Bloom's Taxonomy : What Measurable Verbs Can and Cannot Say about Student Learning.

Sternberg. R. J. (2006). The Nature of Creativity. Creativity Research Journal. 2006, Vol. 18, No. 1, 87-98.

Suarma, D. M., \& Kusumah, Y. S. 2016. Interaksi Antara Faktor Tkam Dan Pembelajaran Terhadap Kemampuan Penalaran Deduktif Matematis Mahasiswa Calon Guru SD Beserta Kinerjanya. EDUHUMANIORA: Jurnal Pendidikan Dasar, 4(1).

Tindowen, D. J. C., Bassig, J. M., \& Cagurangan, J. A. 2017. Twenty-FirstCentury Skills of Alternative Learning System Learners. SAGE Open, 7(3), 1-8. https://doi.org/10.1177/215824401772611 6

Tsai, C.Y., Horng, JS, Liu, CH, Hu, DC, Chung YC. (2015). Awakening student creativity: Empirical evidence in a learning environment context. Journal of Hospitality, Leisure, Sport \& Tourism Education, 17, 28-38.
Vale, I. \& Barbosa, A. 2015. Mathematics Creativity in Elementary Teacher Training. Journal of the European Teacher Education Network. Vol. 10, 101109.

Wahyudi, Waluya, B. 2017. The Importance of Cognitive Psychology in Mathematics Learning and Students' Creativity. In Proceeding International Conference on Mathematics, Science, and Education (ICoMSE). Malang State University. Malang.

Wahyudi, Waluya, B., Rochmad, \& Suyitno, H. 2018. Mathematical Creative Thinking Ability And Scaffolding Process According With Learning Styles For PreService Teachers. Anatolian Journal of Instruction, 3(1), 39-50.

Wahyudi, Waluya, B., \& Rochmad. 2018. Scaffolding Based on Learning Style as An Effort to Increase Mathematical Creative Thinking Skill. The International Journal of Research in Teacher Education, 9(1), 34-44.

Zevenbergen, R., Dole, S., \& Wright, R. J. 2004. Teaching mathematics in primary schools. Crows Nest: Allen \& Unwin. 